\title{
Soil Carbon Storage in Experimental Forest Plantations with Tropical Species
}

\section{Celia De La Mora-Orozco ${ }^{*}$, José Germán Flores Garnica ${ }^{2}$, Irma Julieta González Acuña ${ }^{3}$, Juan De Dios Benavides Solorio² ${ }^{2}$ César S. Magaña Martínez ${ }^{4}$, Laura Izascum Pérez Valencia ${ }^{4}$}

\author{
${ }^{1}$ Instituto Nacional de Investigaciones Forestales, Agrícolas y Pecuarias, Tepatitlán, México \\ ${ }^{2}$ Instituto Nacional de Investigaciones Forestales, Agrícolas y Pecuarias, Guadalajara, México \\ ${ }^{3}$ Instituto Nacional de Investigaciones Forestales, Agrícolas y Pecuarias, Santiago Ixcuintla, México \\ ${ }^{4}$ Instituto Tecnológico José Mario Molina Pasquel y Henríquez, Unidad Académica Arandas, Arandas, México \\ Email: ^delamora.celia@inifap.gob.mx
}

How to cite this paper: De La Mora-Orozco, C., Garnica, J. G. F., Acuña, I. J. G., De Dios Benavides Solorio, J., Martínez, C. S. M., \& Valencia, L. I. P. (2022). Soil Carbon Storage in Experimental Forest Plantations with Tropical Species. Open Journal of Forestry, 12, 1-18. https://doi.org/10.4236/ojf.2022.121001

Received: August 29, 2021

Accepted: November 13, 2021

Published: November 16, 2021

Copyright (c) 2022 by author(s) and Scientific Research Publishing Inc. This work is licensed under the Creative Commons Attribution International License (CC BY 4.0).

http://creativecommons.org/licenses/by/4.0/

\begin{abstract}
Forest ecosystems represent a third of the total organic carbon (TOC) stored in the soil. However, studies still need to be carried out to generate reliable information on its soil carbon storage potential in an experimental plantation. Therefore, the objective of this research was to determine the storage of total organic carbon (TOC) in the soil in two experimental forest plantations with tropical species, located in the state of Nayarit, México. The research was carried out in two experimental plantations with tropical species, located at the Santiago Ixcuintla Experimental Field (CESIX) and at the El Verdineño Experimental Site (SEEV). The established species are Swietenia macrophylla King (mahogany), Cedrela odorata L. (cedar) and Tabebuia rosea Bertoil (pink trumpet-tree). In addition, data from dasometric variables were used in order to define if any of these variables had a similar variation to the soil TOC stock by species. The sampling was done under a randomized block experimental design in each experimental forest plantation (CESIX and SEEV). Nine composite samples were collected in the soil under the tree species at a depth of $0-30 \mathrm{~cm}$, and $1.5 \mathrm{~m}$ distance from the tree. To determine the soil TOC, an elemental analyzer with a thermal conductivity detector Thermo Scientific (Flash 2000) was used. The results showed that TOC presented mean values of 103.60 and $219.98 \mathrm{t}^{\mathrm{h}} \mathrm{h}^{-1}$ at a depth of $0-30 \mathrm{~cm}$ in CESIX and SEEV respectively. The highest TOC was obtained in soil under mahogany; $142.95 \mathrm{t} \cdot \mathrm{ha}^{-1}$ in CESIX and $284.41 \mathrm{t} \cdot \mathrm{ha}^{-1}$ in SEEV. The analysis of the differences in TOC between the two plantations was highly significant. In the analysis of the species, it showed a statistically significant difference $(p<0.0001)$, defining that the soil under the mahogany, in general, presented the highest stock of TOC. Regarding the TOC in the soil plantation and the dasometric
\end{abstract}


variables, none of the variables analyzed showed the same behavior in its va-

riability.

\section{Keywords}

Carbon Sequestration, Dasometric Variables, Tropical Trees

\section{Introduction}

In recent decades, the importance of forest ecosystems has been recognized in mitigating global climate change, due to their high carbon capture and storage capacity. Specifically, these ecosystems have the capacity to store between 1.3 and 2 times the amount of $\mathrm{CO}_{2}$ present in the atmosphere C (Lorenz \& Lal, 2009; Houghton, 2007).

Due to the importance of forest ecosystems in mitigating global climate change, in recent decades worldwide, commercial forest plantations have been promoted (CONAFOR, 2011; Cotler et al., 2020). An example of its importance is that they can store 39.4 and $64.5 \mathrm{t} \mathrm{C} \mathrm{ha}^{-1}$ (Cerda Bustillos et al., 2013; Andrade et al., 2013).

On the other hand, the tree structural attributes are especially important in a forest plantation, the fundamental tree variables involving in a forest productivity plantations are; diameter at breast height, mean height, basal area and volume. Moreover, abiotic factors such as; climate, annual average temperature and annual precipitation are correlated with forest productivity either to soil carbon stock (Amundson, 2001; Kuznetsova et al., 2021).

Nevertheless, tree species in a forest plantation has been reported an important factor related to soil C storage, because the litter inputs in soil may vary depending on tree species in the same plantation (Binkley \& Giardina, 1998; Chen \& Li, 2003; Framstad et al., 2013; Lukina et al., 2020). Another, authors have been reported the correlation between tree species and $\mathrm{C}$ and $\mathrm{N}$ stock in the soil (Chen \& Li, 2003; Han et al., 2017; Augusto et al., 2002). Besides, soil type and parental material (Angst et al., 2018), type of vegetation (Galicia et al., 2016) and the age of the forest site (Casiano-Domínguez et al., 2018), are important for soil carbon storage.

Therefore, estimates of C stocks in forests soil have become relevant at global, national, regional and local scale (Li et al., 2012; Han et al., 2017; Kim et al., 2017).

In this context, research regarding soil $\mathrm{C}$ in natural forest has been reported by several authors; Jordán et al. (2007) mentioned about $124 \mathrm{t} \cdot \mathrm{ha}^{-1}$ (in the Los Alcornocales Natural Park in Cádiz, Spain) at a depth of $0-30 \mathrm{~cm}$, in clay and/or calcareous soil. The authors also mentioned C stock between 76 and 115 tha ${ }^{-1}$, in soils of alluvial origin. Martínez-Navarro et al. (2020) evaluated the soil organic carbon concentration in a temperate forest (Pinus - Quercus spp. stratum, $\mathrm{Q}=$ Quercus spp. Stratum) of the Hueyapa River watershed, within the 
upper $30 \mathrm{~cm}$. They reported soil organic carbon (SOC) fluctuation between 32.71 and $96.68 \mathrm{t} \mathrm{Cha}{ }^{-1}$, an average of $65.52 \mathrm{t} \cdot \mathrm{ha}^{-1}$.

Moreover, the tropical forest potential to sequester $\mathrm{C}$ in soil is of particular interest. According to (Jobbágy \& Jackson, 2000) about 30\% of the soil carbon stock in the planet is in tropical forest. The carbon sequestration potential particularly in tropical forests, is mainly thru conservation of existing forests, reforestation and agroforestry (Lasco \& Pulhin 2003). Lewis et al. (2009) and Malhi (2010) stated that the tropical forest can sequester about $1.3 \times 10^{9} \mathrm{t} \mathrm{C} \mathrm{yr}^{-1}$.

Several researches have been carried out in forests with tropical species. Lasco \& Pulhin (2006) reported a SOC about 30 to $43 \mathrm{t} \cdot \mathrm{ha}^{-1}$ in the plantations at La Mesa Watershed near Manila. Also, Pulhin (2007) in Lasco \& Pulhin 2006 mentioned $14 \mathrm{t} \cdot \mathrm{ha}^{-1}$ soil C in a tropical forest with mahogany. Racelis et al. (2019) reported SOC of $72.63 \mathrm{t} \cdot \mathrm{ha}^{-1}$ in a large leaf Mahogany forest plantation, where an increment of $142 \%$ was detected in a 10 -year period, corresponding to 42.58 $\mathrm{t} \cdot \mathrm{ha}^{-1}$. Furthermore, the $\mathrm{C}$ amount increases to $104 \mathrm{t} \cdot \mathrm{ha}^{-1}$, adding soil and necromass sinks. Sierra et al. (2012) studied the accumulation rates of total carbon in a regrowing tropical forest in the Porce region of Colombia, they reported soil carbon average of $66.5 \pm 28.1 \mathrm{t} \mathrm{Cha}^{-1}$, in the first $30 \mathrm{~cm}$ which represented the second most important ecosystem carbon pool in the research. Saimun et al. (2021), conducted a research at two tropical-protected areas in Bangladesh, the Satchari National Park (SNP), and Khadimnagar National Park (KNP). The authors mentioned soil carbon about $77.1 \mathrm{t} \cdot \mathrm{ha}^{-1}$ in SNP and $130.5 \mathrm{t} \cdot \mathrm{ha}^{-1}$ in KNP.

According to the above, most of the publications related to the total organic carbon in tropical forest plantations were done in Asia and South America, in México there is scarce information about the topic. In this context, more studies are necessary to generate reliable information on the potential for carbon storage in the soil, under different scenarios of tropical forest plantations. The objective of this research was to determine the amount of total organic carbon stored in the soil, under different tropical species, of two experimental forest plantations located in the state of Nayarit, México. In addition, data from dasometric variables was comparatively analyzed in relation to each species, to define if its variation is similar to the variation in the soil C stock.

\section{Materials and Methods}

\subsection{Study Area Location}

The experimental forest plantations included in this research were established in the Experimental Field "Santiago Ixcuintla" (CESIX), and the Experimental Site "El Verdineño" (SEEV), belonging to the Forestry, Agricultural and Livestock Research National Institute (INIFAP). The Santiago Ixcuintla Experimental Field is located in the Municipality of Santiago Ixcuintla, Nayarit, at km. 6 of the México-Nogales International Highway (Figure 1).

The plantations were established in August 1994, with genetic material obtained from the "Camichín de Jauja" forest nursery (Tepic, Nayarit), and were 


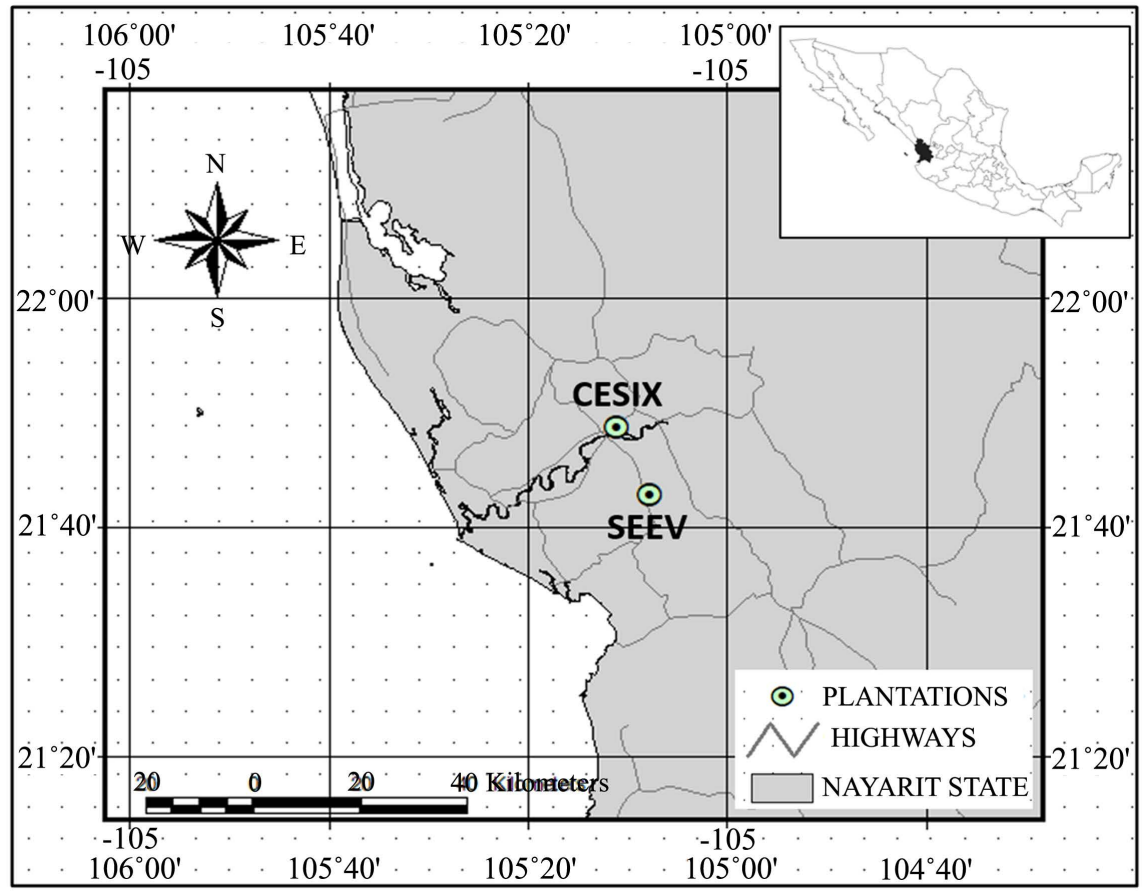

Figure 1. Forest plantations location: "Santiago Ixcuintla" Experimental Field (CESIX) and "El Verdineño" Experimental Site (SEEV).

established under checkered design, with a distance between lines and trees of 4 $\times 4 \mathrm{~m}$. The species in the two experimental forest plantations are: Swietenia macrophylla (mahogany), Cedrela odorata (cedar) and Tabebuia rosea (pink trumpet-tree). Table 1 shows the characteristic of the two study location.

\subsection{Experimental Design}

Since we wanted to determine if there was a significant difference between plantations and between species, the sampling was done under a randomized block experimental design in each experimental forest plantation (CESIX and SEEV). Three subsamples (which were mixed to obtain one composite sample) were collected in the soil under the tree species (mahogany, cedar and pink trumpet-tree), whose individuals were grouped within each plantation, in total, 9 composite samples were obtained for each locality for a total of 16 samples analyzed. The samples were collected at a depth of $0-30 \mathrm{~cm}$, at a distance of $1.5 \mathrm{~m}$ from the tree.

\subsection{Samples Collection}

The samples collection for the determination of total organic carbon (TOC) was carried out in September 2019. They were collected in a soil profile of $0-30 \mathrm{~cm}$, with the arrangement mentioned in the experimental design. The samples were duly identified and placed in plastic bags for their transfer to the laboratory and their subsequent analysis in the Soil Fertility laboratory of the Experimental Field (Santiago Ixcuintla, Nayarit). 
Table 1. Characteristics of the two study locations. CESIX = Santiago Ixcuintla Experimental Field; SEEV = El Verdineño Experimental Site.

\begin{tabular}{ccc}
\hline Characteristics & CESIX & SEEV \\
\hline Geographical location & $21^{\circ} 49^{\prime} 24^{\prime \prime} \mathrm{N}$ & $21^{\circ} 42^{\prime} 12^{\prime \prime} \mathrm{N}$ \\
Elevation (meters) & $105^{\circ} 11^{\prime} 3^{\prime \prime} \mathrm{W}$ & $105^{\circ} 07^{\prime} 48^{\prime \prime} \mathrm{W}$ \\
Climate & 10 & 50 \\
Average annual temperature $\left({ }^{\circ} \mathrm{C}\right)$ & $\mathrm{Aw} 1$ & Aw1 \\
Tmax $\left({ }^{\circ} \mathrm{C}\right)$ & 25.0 & 22.0 \\
Tmin $\left({ }^{\circ} \mathrm{C}\right)$ & 39.0 & 32.0 \\
Precipitation $(\mathrm{mm})$ & 8.5 & 18.0 \\
Soil type & 1300 & 1200 \\
& Fluvisol eutric & Pelic Vertisol \\
(medium texture) & (fine texture) \\
\hline
\end{tabular}

Source: Medina et al. (1998).

\subsection{Sample Preparation}

Drying of the samples. The soil samples were spread in stainless steel trays, to avoid contamination. They were placed in a ventilated and sunny area for approximately five days, the time necessary for it to dry.

Initial weighing of the samples. Two types of weighing were carried out for the soil samples: 1) Wet weight, and 2) Dry weight. Due to the fact that the samples were transferred in plastic bags, unlike what is indicated in the AS-01 protocol (Preparation of the soil sample for mainly physical and soil fertility determinations) issued by SEMARNAT (2002), it is advisable not to weigh the bags immediately, but until after the soil is dry. In this way, the bags are weighed without soil residue.

Cleaning of samples. First, coarse particles and all material that could contaminate the sample, such as plants, roots and trunks, were manually separated.

Crushing and sieving of the samples. Each sample was placed in a grinder and subsequently sieved through a No.10 sieve $(2 \mathrm{~mm})$. The gravels and rock fragments, which did not pass through the sieve were removed from the rest of the sample. These coarse particles $(>2 \mathrm{~mm}$ ) were separated and weighed; Bulk density of the soil, estimated by the graduated cylinder method, was also estimated.

The soil fraction less than $2 \mathrm{~mm}$ was the sample that was analyzed for carbon. This was passed through a cracker to homogenize it and obtain $15 \mathrm{~g}$ of soil, which were ground in an Agate mill that allowed obtaining fine soil, which was passed through a No. 100 sieve (149 microns) (ISO Standard). This sample was placed in envelopes for later analysis.

\subsection{Sample Analysis}

To determine the soil TOC, an elemental analyzer with a thermal conductivity detector Thermo Scientific (Flash 2000) was used, according to the protocol 
proposed by the National Network of Laboratories for the Analysis, Use, Conservation and Management of Soil (REDLAB).

Between 30 to $40 \mathrm{mg}$ of each soil sample were weighed, which were placed in tin capsules, then in a sample plate that feeds the equipment. Once the equipment was stabilized, the relevant instructions for the corresponding analysis were activated.

\subsection{Dasometric Variables Data}

The dasometric variables results utilized in this research were from filed data obtained in 2018, in the two plantations under study. Table 2 shows the dasometric variables, the method and the equipment.

\subsection{Statistical Analysis}

The evaluations of soil TOC stock were evaluated based on a factorial design (2 $\times 3$ ): 1) two forest plantations; and 2) three species for each plantation. In this way, a series of variance analyzes were carried out, where first the ANOVA ( $p \leq$ $0.05)$ corresponding to the factorial design was determined. Subsequently, it was defined if there was any statistically significant difference between the species corresponding to each plantation.

Once the ANOVAs regarding soil TOC stock were determined, the following dasometric variables of each species were analyzed: crown radius, clean stem height, stump diameter, normal diameter, total height, crown height, crown area and crown volume (The results of the dasometric variables of an evaluation carried out in 2018, in the two plantations were used). This in order to define if any of these variables had a similar behavior to the soil TOC stock. These analyzes were made for each of the forest plantations (CESIX and SEEV).

\section{Results}

The average results of the determination of total organic carbon in the soil of the two plantations under study are shown in Table 3. On average, the TOC presented values with marked difference in the two locations, in such a way that the

Table 2. Dasometric variables used in this research, method and equipment.

\begin{tabular}{ccc}
\hline Variable & Method & Equipment \\
\hline Clean stem height & Angle measurement & Clinometer \\
Stump diameter & Direct measurement & Diameter tape \\
Normal diameter & Direct measurement & Diameter tape \\
Total height & Direct measurement & Stadal \\
Crown height & Angle measurement & Clinometer \\
Crown area & Area equation & Linear tape \\
Crown volume & Volume equation & Linear tape/clinometer \\
Crown radius & Direct measurement & Linear tape
\end{tabular}


Table 3. Soil total organic carbon, by plantation and by species. CESIX = Santiago Ixcuintla Experimental Field; SEEV = El Verdineño Experimental Site.

\begin{tabular}{cccc}
\hline Plantation & Species & Common name & t.ha $^{-1}$ \\
\hline \multirow{2}{*}{ CESIX } & Cedrela odorata & Cedar & 83.49 \\
(Fluvisol Soil) & Swietenia macrophylla & Mahogany & 142.95 \\
& Tabebuia rosea & Pink trumpet tree & 84.37 \\
& & & $103.60 \pm 34.07$ \\
SEEV & Cedrela odorata & Cedar & 190.78 \\
(Vertisol Soil) & Swietenia macrophylla & Mahogany & 284.41 \\
& Tabebuia rosea & Pink trumpet tree & 184.75 \\
& & & $219.98 \pm 55.87$ \\
\hline
\end{tabular}

TOC in SEEV represented more than double that of the TOC contained in the soil of CESIX. The results showed that the highest TOC amount were obtained in the soil samples collected under mahogany, both in the CESIX and in the SEEV. However, again, the TOC stock under mahogany soil was more than double in SEEV, compared to CESIX mahogany, resulting in a difference of $141.46 \mathrm{t} \cdot \mathrm{ha}^{-1}$.

On the other hand, the average TOC stock in soil under cedar and pink trumpet-tree, in the CESIX plantation, presented a minimum difference of 0.88 $\mathrm{t} \cdot \mathrm{ha}^{-1}$. A similar trend was presented in the SEEV, with a difference of $6.03 \mathrm{t} \cdot \mathrm{ha}^{-1}$.

\subsection{Carbon Stock Variation}

The analysis of the differences of the carbon stock, between the two plantations, was highly significant (Table 4), which was expected because the TOC in the SEEV soil is more than double that in the CESIX plantation. However, in the case of the analysis of the species, although, if a statistically significant difference was determined $(p<0.0001)$, the results of the Tukey test (Figure 2$)$ defined that: 1) the lowest content of stored TOC corresponded to the ground under the trees of pink trumpet tree and cedar; and 2) on the contrary, the soil under mahogany, in general, was the species that presented the highest TOC stock.

Comparing the TOC stored in the soil under the species that are located in the SEEV, a significant difference was presented (Table 4). In accordance with this, Figure 3 shows, firstly, a different response to the one presented considering the total of the species (SEEV and CESIX). In this case, mahogany is the species under which the highest soil stock was evaluated, being different from TOC stored in the soil under cedar and pink trumpet tree. However, between the latter it was not determined that there was a statistically significant difference.

As in the SEEV, the stock of TOC stored in the soil under the species that are located in the CESIX presented a significant difference (Table 4). Similarly, it is observed that mahogany is the species under which the highest soil stock was evaluated (Figure 4), being different from TOC stored in the soil under cedar and pink trumpet-tree. However, between the latter it was not determined that there was a statistically significant difference. 


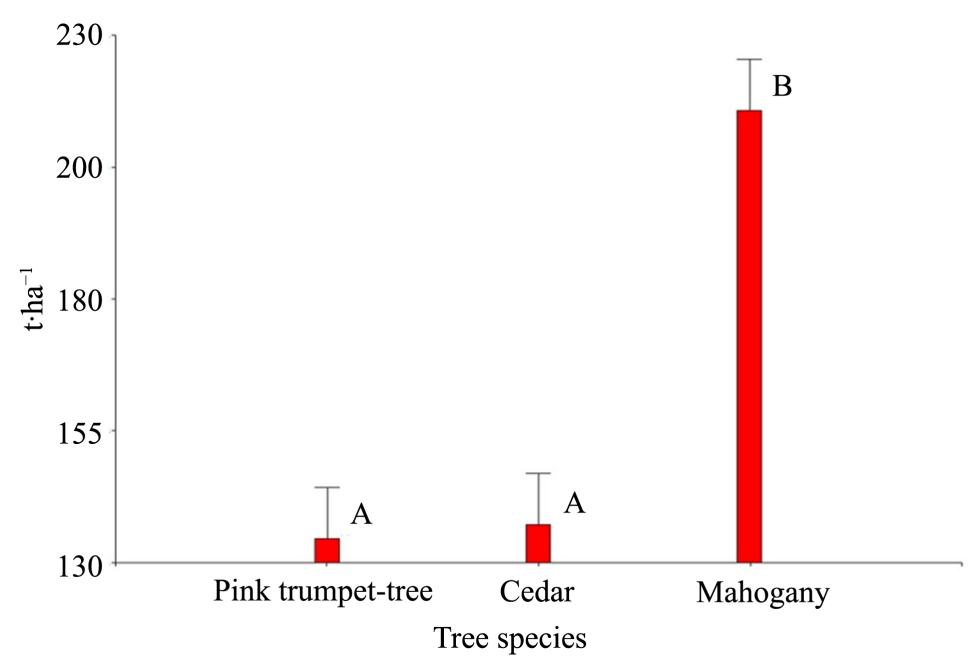

Figure 2. Soil total organic carbon stock comparison, in the SEEV and CESIX species as a whole.

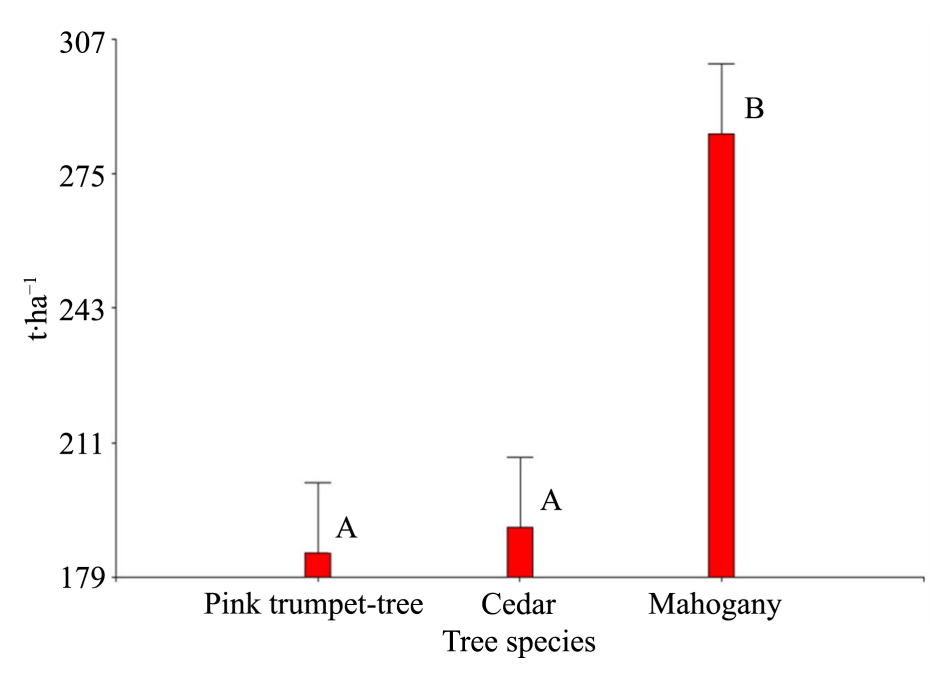

Figure 3. Soil total organic carbon stock comparison, in the SEEV species.

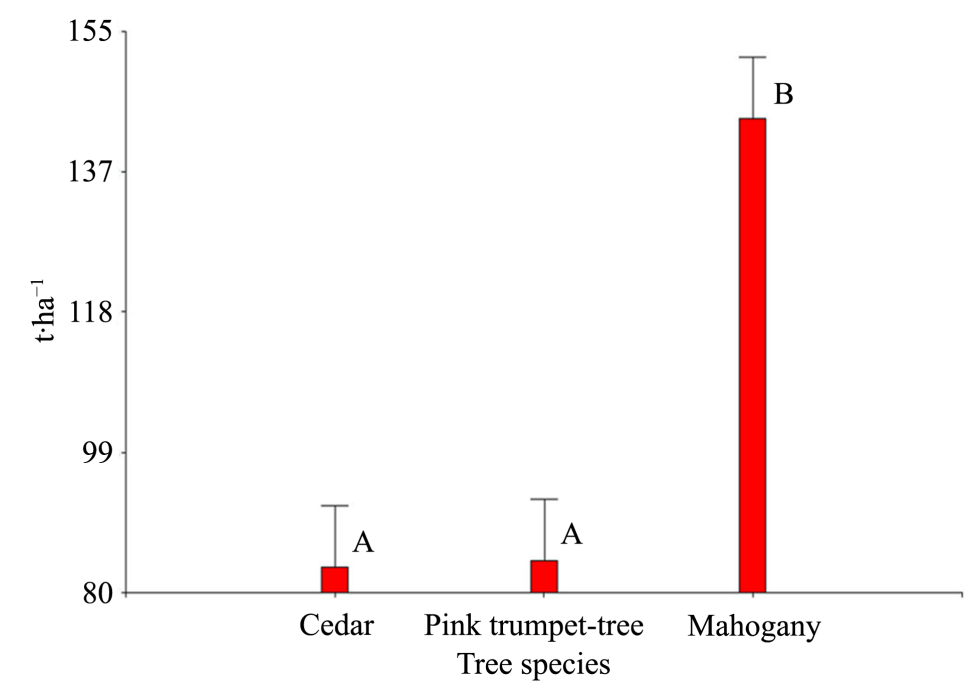

Figure 4. Soil total organic carbon stock comparison, in the CESIX species. 
Table 4. Soil total organic carbon, by plantation and by species. CESIX = Santiago Ixcuintla Experimental Field; SEEV = El Verdineño Experimental Site.

\begin{tabular}{cccc}
\hline Comparison & Factor & F & $p$-value \\
\hline \multirow{2}{*}{ Between plantations } & Plantation & 112.53 & $<0.0001$ \\
& Species & 22.67 & $<0.0001$ \\
SEEV & Species & 11.36 & 0.0091 \\
CESIX & Species & 17.81 & 0.0030 \\
\hline
\end{tabular}

\subsection{Dasometric Variation (CESIX)}

In the plantation located in the CESIX, 513 trees were evaluated, corresponding to the species of mahogany, cedar and pink trumpet-tree, which presented, as a whole, the following means of the dasometric variables: Normal diameter (DN) $=24.49 \mathrm{~cm}$; Stump diameter $(\mathrm{DT})=29.48 \mathrm{~cm}$; Total height $(\mathrm{AT})=12.54 \mathrm{~m}$; Clean stem height $(\mathrm{AFL})=4.21 \mathrm{~m}$; Crown diameter $(\mathrm{DC})=5.76 \mathrm{~m}$; Crown area $(\mathrm{AC})=31.52 \mathrm{~m}^{2}$; Crown height $(\mathrm{ALC})=8.33 \mathrm{~m}$; Crown radius $(\mathrm{RC})=3.52 \mathrm{~m}$; Crown volume $(\mathrm{VC})=272.68 \mathrm{~m}^{3}$. Table 5 presents the same statistics, but for each of the species that were located in the CESIX plantation.

Each of these dasometric variables is comparatively analyzed in relation to each species, this with the purpose of defining if its variation is similar to the variation in the TOC stock in the soil (Figure 5). Where there is no significant difference between cedar and pink trumpet-tree, but there is between these two variables with mahogany. According to this, none of the variables analyzed showed the same behavior in its variability, where one would expect mahogany, (which presented the highest stock of TOC in the soil) to be the species with the largest dimensions. On the contrary, the pink trumpet-tree is the species that presents the highest values in the dasometric variables, and, in most cases, it is significantly different from the other two species. Regarding cedar and mahogany, these species alone did not present a significant difference in relation to AFL and DT. Whereas, when comparing cedar with pink trumpet-tree, there was only no difference in relation to DN, AC and RC. In the cases of AT, DC, ALC and $\mathrm{VC}$, the three species were significantly different.

\subsection{Dasometric Variation (SEEV)}

In the SEEV plantation, 422 trees were evaluated, corresponding to the species of mahogany, cedar and pink trumpet-tree, which presented, as a whole, the following means of the dasometric variables: Normal diameter $(D N)=22.58 \mathrm{~cm}$; Stump diameter $(\mathrm{DT})=28.21 \mathrm{~cm}$; Total height $(\mathrm{AT})=11.23 \mathrm{~m}$; Clean stem height $(\mathrm{AFL})=3.33 \mathrm{~m}$; Crown diameter $(\mathrm{DC})=3.49 \mathrm{~m}$; Crown area $(\mathrm{AC})=$ $12.56 \mathrm{~m}^{2}$; Crown height $(\mathrm{ALC})=7.89 \mathrm{~m}$; Crown radius $(\mathrm{RC})=2.84 \mathrm{~m}$; Crown volume $(\mathrm{CV})=139.60 \mathrm{~m}^{3}$. Table 6 presents the same statistics, but for each of the species that were located in the SEEV plantation.

As in the CESIX plantation, each SEEV dasometric variable was comparatively analyzed in relation to each species, to define if its variation is similar to the 
Table 5. Statistics for each species by plantation and by species. CESIX = Santiago IXcuintla Experimental Field.

\begin{tabular}{|c|c|c|c|c|c|c|c|}
\hline Species & Variable & $\mathrm{n}$ & Mean & S.D. & V.C. & Minimum & Maximum \\
\hline Mahogany & DN & 183 & 24.63 & 7.32 & 29.71 & 8.80 & 47.00 \\
\hline Mahogany & DT & 183 & 28.78 & 7.70 & 26.74 & 10.40 & 50.90 \\
\hline Mahogany & $\mathrm{AT}$ & 183 & 11.88 & 2.46 & 20.72 & 5.34 & 18.85 \\
\hline Mahogany & AFL & 183 & 3.59 & 1.97 & 54.86 & 1.07 & 14.84 \\
\hline Mahogany & $\mathrm{DC}$ & 183 & 6.34 & 2.45 & 38.56 & 2.20 & 15.78 \\
\hline Mahogany & $\mathrm{AC}$ & 183 & 36.27 & 28.54 & 78.69 & 3.80 & 195.45 \\
\hline Mahogany & ALC & 183 & 8.29 & 2.94 & 35.47 & 0.00 & 15.78 \\
\hline Mahogany & $\mathrm{RC}$ & 183 & 3.66 & 1.15 & 31.38 & 0.55 & 6.86 \\
\hline Mahogany & $\mathrm{VC}$ & 183 & 264.31 & 219.86 & 83.18 & 0.70 & 1353 \\
\hline Cedar & DN & 128 & 21.31 & 6.42 & 30.11 & 7.00 & 41.40 \\
\hline Cedar & DT & 128 & 27.48 & 7.35 & 26.75 & 10.00 & 50.20 \\
\hline Cedar & $\mathrm{AT}$ & 128 & 10.02 & 2.87 & 28.66 & 3.70 & 14.95 \\
\hline Cedar & AFL & 128 & 3.54 & 2.24 & 63.33 & 1.71 & 13.08 \\
\hline Cedar & DC & 128 & 3.64 & 1.98 & 54.50 & 0.00 & 10.36 \\
\hline Cedar & $\mathrm{AC}$ & 128 & 13.48 & 13.90 & 103.08 & 0.00 & 84.22 \\
\hline Cedar & ALC & 128 & 6.48 & 3.06 & 47.32 & 0.00 & 11.98 \\
\hline Cedar & $\mathrm{RC}$ & 128 & 2.53 & 1.09 & 43.03 & 0.68 & 5.46 \\
\hline Cedar & VC & 128 & 106.7 & 120.12 & 112.58 & 1.33 & 683.22 \\
\hline Pink Trumpet-tree & $\mathrm{DN}$ & 202 & 26.36 & 9.04 & 34.31 & 4.00 & 58.30 \\
\hline Pink Trumpet-tree & DT & 202 & 31.29 & 10.30 & 32.81 & 6.50 & 68.30 \\
\hline Pink Trumpet-tree & $\mathrm{AT}$ & 202 & 14.73 & 3.46 & 23.51 & 3.08 & 22.10 \\
\hline Pink Trumpet-tree & AFL & 202 & 5.2 & 3.49 & 67.15 & 0.95 & 20.35 \\
\hline Pink Trumpet-tree & DC & 202 & 6.58 & 2.44 & 37.08 & 0.17 & 12.43 \\
\hline Pink Trumpet-tree & $\mathrm{AC}$ & 202 & 38.65 & 25.35 & 65.59 & 0.02 & 121.35 \\
\hline Pink Trumpet-tree & ALC & 202 & 9.53 & 4.35 & 45.66 & 0.00 & 19.26 \\
\hline Pink Trumpet-tree & $\mathrm{RC}$ & 202 & 4.03 & 1.53 & 37.88 & 0.50 & 7.12 \\
\hline Pink Trumpet-tree & VC & 202 & 385.45 & 327.66 & 85.01 & 0.52 & 1512.72 \\
\hline
\end{tabular}

$\mathrm{DN}=$ normal diameter $(\mathrm{cm}) ; \mathrm{DT}=$ Stump diameter $(\mathrm{cm}) ; \mathrm{AT}=$ Total height $(\mathrm{m}) ; \mathrm{AFL}=$ Height of clean stem $(\mathrm{m}) ; \mathrm{DC}=$ Crown diameter $(\mathrm{m}) ; \mathrm{AC}=$ Crown area $\left(\mathrm{m}^{2}\right) ; \mathrm{ALC}=$ Crown height $(\mathrm{m}) ; \mathrm{RC}=$ Crown radius $(\mathrm{m}) ; \mathrm{VC}=$ Crown volume $\left(\mathrm{m}^{3}\right)$.

Table 6. Soil total organic carbon stock, by plantation and by species. SEEV = El Verdineño Experimental Site.

\begin{tabular}{cccccccc}
\hline Species & Variable & $\mathrm{n}$ & Mean & S.D. & V.C. & Minimum & Maximum \\
\hline Mahogany & DN & 73 & 21.55 & 5.66 & 26.26 & 10.50 & 42.80 \\
Mahogany & DT & 73 & 25.08 & 6.56 & 26.15 & 3.40 & 47.50 \\
Mahogany & AT & 73 & 10.11 & 1.45 & 14.39 & 7.15 & 13.10 \\
Mahogany & AFL & 73 & 2.57 & 0.91 & 35.34 & 1.31 & 5.20 \\
\hline
\end{tabular}




\section{Continued}

\begin{tabular}{cccccccc}
\hline Mahogany & DC & 73 & 4.08 & 1.74 & 42.61 & 1.26 & 10.43 \\
Mahogany & AC & 73 & 15.38 & 13.64 & 88.68 & 1.25 & 85.36 \\
Mahogany & ALC & 73 & 7.54 & 1.54 & 20.43 & 2.86 & 10.84 \\
Mahogany & RC & 73 & 2.90 & 0.67 & 23.14 & 1.03 & 4.53 \\
Mahogany & VC & 73 & 118.75 & 78.47 & 66.08 & 4.58 & 389.07 \\
Cedar & DN & 137 & 18.74 & 5.28 & 28.19 & 6.90 & 31.50 \\
Cedar & DT & 137 & 24.61 & 5.78 & 23.49 & 11.00 & 39.50 \\
Cedar & AT & 137 & 9.43 & 2.26 & 23.98 & 3.68 & 14.00 \\
Cedar & AFL & 137 & 2.83 & 1.57 & 55.55 & 1.25 & 11.50 \\
Cedar & DC & 137 & 2.37 & 1.65 & 69.40 & 0.00 & 6.65 \\
Cedar & AC & 137 & 6.52 & 8.01 & 122.85 & 0.00 & 34.68 \\
Cedar & ALC & 137 & 6.59 & 2.32 & 35.22 & 0.47 & 11.27 \\
Cedar & RC & 137 & 2.24 & 0.87 & 38.72 & 0.30 & 4.38 \\
Cedar & VC & 137 & 68.38 & 67.13 & 98.16 & 0.11 & 352.58 \\
Pink Trumpet-tree & DN & 212 & 27.45 & 8.63 & 31.44 & 3.40 & 44.90 \\
Pink Trumpet-tree & DT & 212 & 34.95 & 11.79 & 33.74 & 3.05 & 75.60 \\
Pink Trumpet-tree & AT & 212 & 14.15 & 3.21 & 22.70 & 4.70 & 20.35 \\
Pink Trumpet-tree & AFL & 212 & 4.60 & 2.62 & 57.02 & 1.52 & 13.15 \\
Pink Trumpet-tree & DC & 212 & 4.02 & 2.00 & 49.68 & 0.18 & 8.85 \\
Pink Trumpet-tree & AC & 212 & 15.77 & 13.96 & 88.54 & 0.02 & 61.51 \\
Pink Trumpet-tree & ALC & 212 & 9.55 & 3.68 & 38.56 & 2.06 & 16.18 \\
\hline Trumpet-tree & RC & 212 & 3.39 & 1.28 & 37.88 & 0.69 & 6.07 \\
\hline & VC & 212 & 231.67 & 204.36 & 88.21 & 1.35 & 935.66 \\
\hline
\end{tabular}

$\mathrm{DN}=$ normal diameter $(\mathrm{cm}) ; \mathrm{DT}=$ Stump diameter $(\mathrm{cm}) ; \mathrm{AT}=$ Total height $(\mathrm{m}) ; \mathrm{AFL}=$ Height of clean stem $(\mathrm{m}) ; \mathrm{DC}=$ Crown diameter $(\mathrm{m}) ; \mathrm{AC}=$ Crown area $\left(\mathrm{m}^{2}\right) ; \mathrm{ALC}=$ Crown height $(\mathrm{m})$; $\mathrm{RC}=$ Crown radius $(\mathrm{m}) ; \mathrm{VC}=$ Crown volume $\left(\mathrm{m}^{3}\right)$.

variation in the $\mathrm{C}$ stock in the soil (Figure 6). Where there is no significant difference between pink trumpet-tree and cedar, but there is a difference between these two variables with mahogany. According to this, none of the dasometric variables analyzed showed a similar behavior in its variability, where mahogany (which presented the highest stock of $\mathrm{C}$ in the soil) would be expected to be the species with the largest dimensions. On the contrary, as in the case of CESIX, the pink trumpet-tree is the species that presents the highest values in the dasometric variables, and, in most cases, it is significantly different from the other two species. The only exception was the crown diameter (DC) and crown area (AC), where both mahogany and pink trumpet-tree show similar variability, which differentiates it from cedar. Regarding cedar and mahogany, these species alone did not present a significant difference in relation to DT, AT, AFL, ALC and VC. While, when comparing cedar with pink trumpet-tree, a statistically significant difference was found in all variables. In the cases of DN and RC, the three species were significantly different. 


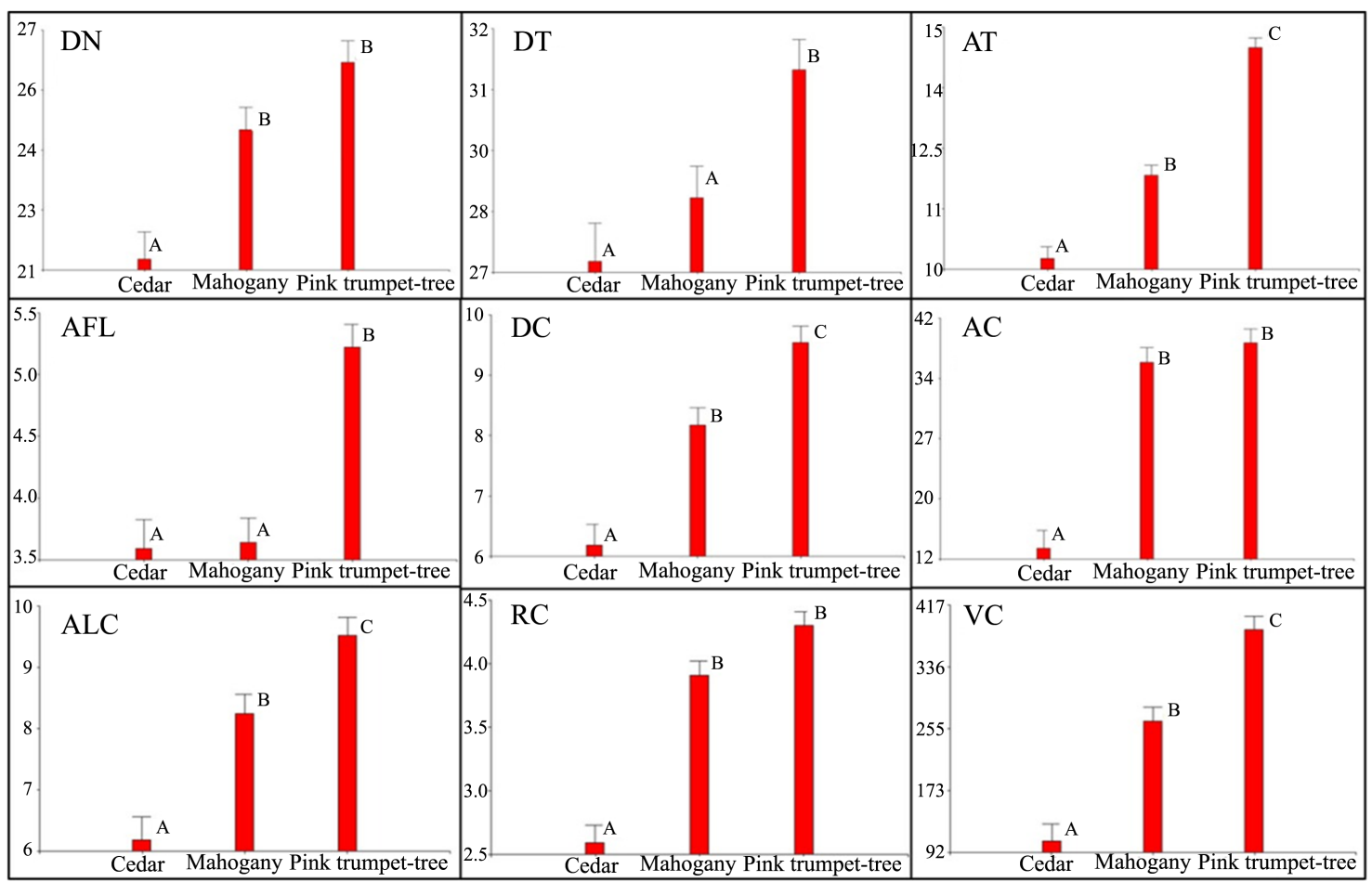

Figure 5. Comparison of the dasometric variables of the species that are located in the CESIX. DN = normal diameter $(\mathrm{cm}) ; \mathrm{DT}=$ Stump diameter $(\mathrm{cm})$; AT $=$ Total height $(\mathrm{m}) ; \mathrm{AFL}=$ Height of clean stem $(\mathrm{m}) ; \mathrm{DC}=$ Crown diameter $(\mathrm{m})$; AC $=$ Crown area $\left(\mathrm{m}^{2}\right) ; \mathrm{ALC}=$ Crown height $(\mathrm{m}) ; \mathrm{RC}=$ Crown radius $(\mathrm{m}) ; \mathrm{VC}=$ Crown volume $\left(\mathrm{m}^{3}\right)$.

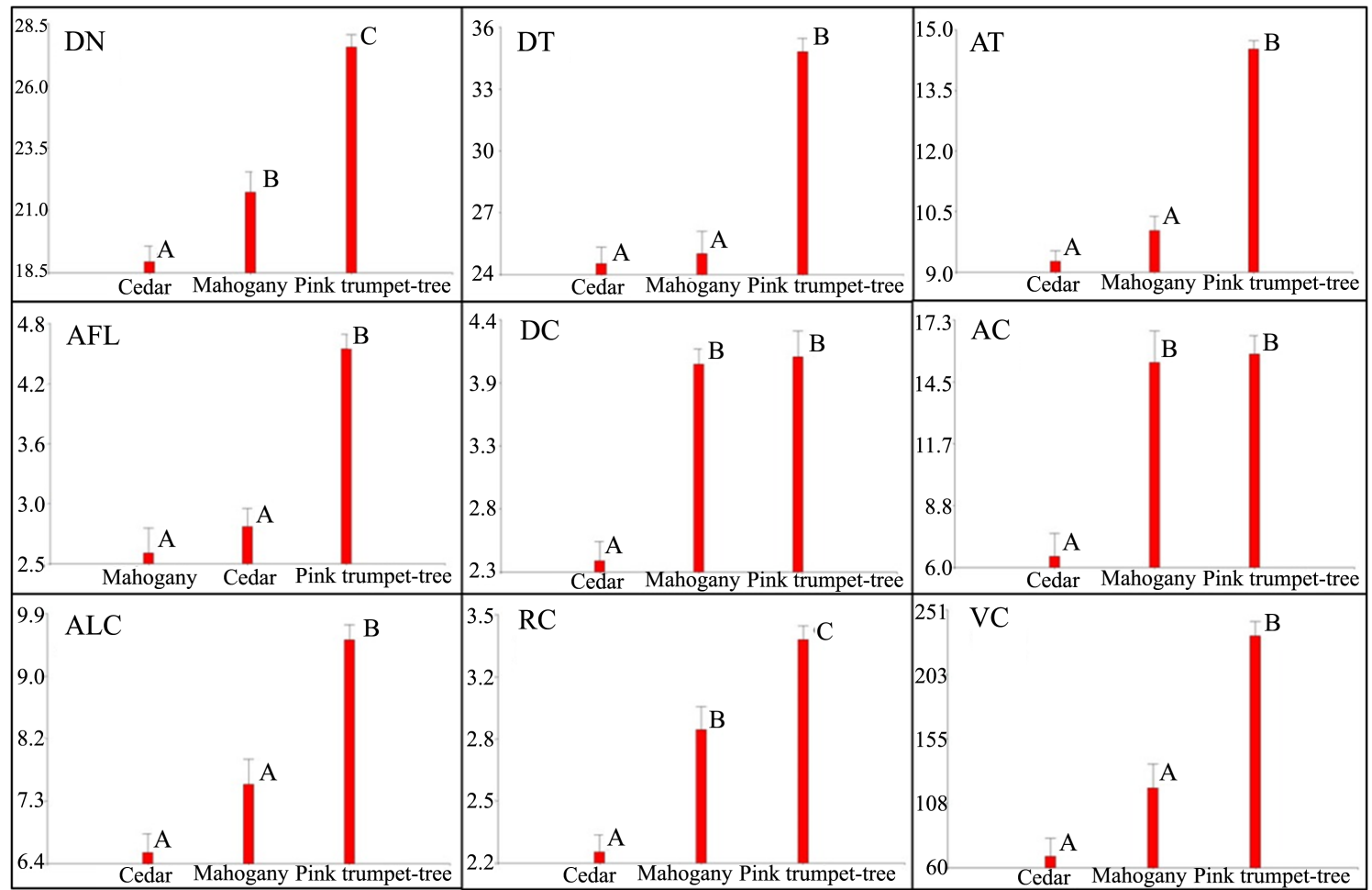

Figure 6. Comparison of the dasometric variables of the species that are located in the SEEV. DN $=$ normal diameter $(\mathrm{cm}) ; \mathrm{DT}=$ Stump diameter $(\mathrm{cm})$; AT $=$ Total height $(\mathrm{m}) ;$ AFL $=$ Height of clean stem $(\mathrm{m}) ; \mathrm{DC}=$ Crown diameter $(\mathrm{m})$; AC $=$ Crown area $\left(\mathrm{m}^{2}\right) ; \mathrm{ALC}=$ Crown height $(\mathrm{m}) ; \mathrm{RC}=$ Crown radius $(\mathrm{m}) ; \mathrm{VC}=$ Crown volume $\left(\mathrm{m}^{3}\right)$. 


\section{Discussion}

Significant differences were observed in the amount of total organic carbon between the two plantations and among the soil under the tree species. These results can be attributed to abiotic variables such as the climate and a greater adaptation of mahogany in the SEEV plantation. The stock of TOC under mahogany soil showed higher values compared to the TOC in soil under the other species in both plantation (CESIX and SEEV). It is also suggested that the type of soil may have an influence on the amount of soil C, since in CESIX the type the soil is Fluvisol eutric (medium texture) and it is varied with coarse sand in the dikes and heavy clays in settling adjacent to the river basins (Bojórquez et al. 2007). And the type of soil in the SEEV is Pelic Vertisol (fine texture) these soils are mainly located in tropical, subtropical, semi-arid to sub-humid and humid climates with high clay stock (Coulombe et al., 2000). Besides, Saimun et al. (2021), stated that soil carbon is negatively correlated with soil sand\%, and Bosatta \& Ågren (1997) in Saimun et al., (2021) stated that the increases of sand\% in soil decreases the organic carbon decomposition. According to Bojórquez et al. (2006), Vertisols are soils with great productive potential. It is suggested that the soil characteristics could influence the higher soil C stock in SEEV plantation.

Moreover, the species at the plantation are particularly important, since the root and litter production, income higher organic inputs which eventually increases the soil carbon (Brown \& Lugo, 1992). Therefore, the soil carbon accumulation rate may be influenced by environmental factors and differences in species (Brown \& Lugo, 1992). In this context, the Swietenia macrophylla, which was the specie under the highest amount of carbon in the soil was obtained, is also called large-leaf mahogany. Therefore, the species effects must be considered in forest plantations for enhancing $\mathrm{C}$ sequestration. According to Racelis et al. (2019) and considering the results in the present study, mahogany has peculiarities that make it a species with high carbon accumulation in soil under the particular environmental and management conditions of this study. It can be suggested that two particular physical characteristics may contribute to the higher $\mathrm{C}$ amount in soil under the mahogany at the experimental plantations (CESIX and SEEV): 1) the large leaf, and 2) the high leaf density. Those two characteristics were particularly notables visually at the two plantation under study.

On the other hand, the results obtained in the present research at CESIX with soil TOC average of $103.60 \mathrm{t} \cdot \mathrm{ha}^{-1}$ from the three species in the plantation, are bellow to the ranges reported by Jordán et al. (2007), which obtained values around $124 \mathrm{t} \cdot \mathrm{ha}^{-1}$ of C in natural forest; Los Alcornocales Natural Park in Cádiz, Spain. Still, the soil TOC average at the SEEV $\left(219.98 \mathrm{t} \cdot \mathrm{ha}^{-1}\right)$ is above to the results reported by Jordán et al. (2007). Moreover, the TOC by specie at the SEEV $\left(184.75,190.78\right.$ and $284.41 \mathrm{t} \cdot \mathrm{ha}^{-1}$, for pink trumpet tree, cedar and mahogany respectively) was above to the ranges reported by Jordán et al. (2007). However, 
it is important to comment that the environment and the species were different that the present study. The same tendency as the mentioned before, was observed to the results reported by Rojas-García et al. (2017) about $130 \mathrm{t} \cdot \mathrm{ha}^{-1}$ of organic carbon in soil forest plantation, in reference to the results in this research at the two plantations.

On the other hand, the soil TOC results in the present study were above some research carried out in forest with tropical species reported in the literature. For example, Lasco and Pulhin (2006) reported soil C about 60.1 thha ${ }^{-1}$ in a dipterocarp forest with more than 20 years in Manila, it has to be noticed that the lower soil TOC amount in the present study was $83.49 \mathrm{t} \cdot \mathrm{ha}^{-1}$, value corresponding to the soil under cedar at CESIX plantation. It can be observed that is the double with respect to the Manila plantation. And is remarkable lower in comparison with the results in the soil under mahogany at SEEV with a soil TOC amount about $284.41 \mathrm{t} \cdot \mathrm{ha}^{-1}$. It is important to comment that even though the forest had similar age (about 20-years), the differences may be attributable to the different tree species.

Furthermore, the results reported by Pulhin (2007) in a tropical forest with mahogany were considerably different ( $14 \mathrm{t} \cdot \mathrm{ha}^{-1}$ soil C) compared to the average results obtained in the present research $\left(142.95 \mathrm{t} \cdot \mathrm{ha}^{-1}\right.$ and $284.41 \mathrm{t} \cdot \mathrm{ha}^{-1}$ at CESIX and SEEV respectively). Additionally, the results in the present research at CESIX, soil TOC under cedar and pink trumpet tree at CESIX plantation were close to the results reported by Racelis et al. (2019) with C of $72.63 \mathrm{th} \mathrm{ha}^{-1}$ in a large leaf mahogany forest plantation. However, the soil $\mathrm{C}$ results reported by Racelis et al. (2019) from mahogany plantation were lower in comparison with the soil TOC amount under mahogany at both plantations under study at CESIX and SEEV respectively.

On the other hand, as a secondary objective, data from the dasometric variables was used to carried out a comparative analysis in relation to each species, to define if its variation is similar to the variation in the TOC stock in the soil. The primary question was whether the mean of soil TOCC varies the same as the means of any of the dasometric variables. In this context, results at CESIX and SEEV demonstrated that, none of the variables analyzed showed the same behavior in its variability, where one would expect mahogany, (which presented the highest stock of TOC in the soil) to be the species with the largest dimensions. It is important to comment that, no literature was found to compare the results of this research regarding the dasometric variables and its similitude with the soil TOC stock. However, Saimun et al. (2021) quantify the tree and soil carbon storage capacity and explored how these carbon storages are associated with average tree height, total tree basal area and stem density in tropical forest ecosystems. They stated, a negative correlation among soil carbon and average tree height $(\mathrm{m})(\mathrm{r}=-0.36, p<0.001)$, total tree basal area $\left(\mathrm{m}^{2} \mathrm{ha}^{-1}\right)(\mathrm{r}=-0.19, p<$ $0.05)$ and stem density (trees ha $\left.{ }^{-1}\right)(\mathrm{r}=-0.11, p=0.22)$ in a tropical forest ecosystem in Bangladesh. In the present study, no correlation was done among the soil $\mathrm{C}$ and the dasometric variables. Therefore, it is desirable to carry out these 
correlations between the dasometric variables and the amount of carbon in the soil, it is suggested to do it in subsequent studies.

\section{Conclusion}

The storage of soil TOC stock under mahogany at the present research was higher than that reported in other forests with tropical species in Asia, even higher than those reported for the same species. According to that, it is necessary to continue investigating, to determine what the particular conditions are that affect higher soil C stock in CESIX and SEEV plantation in Nayarit.

The TOC stock was higher in the soil located under the mahogany trees, attributable to the species due to its larger types of leaf. While no significant difference was found between cedar and pink trumpet-tree. This suggests carrying out a specific analysis of the foliage and aerial biomass of mahogany, to determine if there are particular characteristics that make this species increase the amount of carbon in the soil. According to Brown \& Lugo (1992), some species produce more litter and roots and thus, produce more organic inputs, which eventually influence soil carbon. Therefore, additional research is suggested to corroborate the results of this study.

Results demonstrated that the soil $\mathrm{C}$ under mahogany has a higher potential to store carbon under the specific environmental conditions presented in this research. Moreover, appropriate management interventions could increase the experimental plantation capacity to sequester and storage carbon in soil. It is expected that both experimental plantations increase the carbon over time, since the soil carbon increases, as the vegetation matures.

The results showed that the amount of carbon in the soil in the two plantations was closer to those reported in temperate forests compared to forests with tropical species even with the same species.

Regarding the analysis of the dasometric variables, these did not present a similar behavior to that of $\mathrm{C}$ in the soil, in this context, it is suggested to carry out more in-depth analyses to determine if there are correlations between the dasometric variables and the amount of $\mathrm{C}$ in the soil.

\section{Acknowledgements}

The authors acknowledge the Ing. Clen Becerra Zamorano for his support in field sample collection and laboratory analysis.

\section{Conflicts of Interest}

The authors declare no conflicts of interest regarding the publication of this paper.

\section{References}

Amundson, R. (2001). The Carbon Budget in Soils. Annual Review of Earth and Planetary Sciences, 29, 535-562.

Andrade, H. J., Figueroa, J. M. D. P., \& Silva, D. P. (2013). Almacenamiento de carbono 
en cacaotales (Theobroma cacao) en Armero-Guayabal (Tolima, Colombia).

Angst, G., Messinger, J., Greiner, M., Häusler, W., Hertel, D., Kirfel, K., \& Mueller, C. W. (2018). Soil Organic Carbon Stocks in Topsoil and Subsoil Controlled by Parent Material, Carbon Input in the Rhizosphere, and Microbial-Derived Compounds. Soil Biology and Biochemestry, 122, 19-30.

Augusto, L., Ranger, J., Binkley, D., \& Rothe, A. (2002). Impact of Several Common Tree Species of European Temperate Forests on Soil Fertility. Annals of Forest Science, 59, 233-253.

Binkley, D., \& Giardina, C. (1998). Why Do Tree Species Affect Soils? The Warp and Woof of Tree-Soil Interactions. Biogeochemistry, 42, 89-106.

Bojórquez, I., Hernández, A., García, D., Nájera, O., Flores, F., Madueño, A., \& Bugarín, R. (2006). Características de los suelos cambisoles y fluvisoles de la llanura costera norte del estado de Nayarit, México. Cultivos Tropicales, 28, 19-24.

Bosatta, E., \& Ågren, G. I. (1997). Theoretical Analyses of Soil Texture Effects on Organic Matter Dynamics. Soil Biology \& Biochemistry, 29, 1633-1638.

Brown, S. \& Lugo, A. E. (1992). Aboveground Biomass Estimations for Tropical Moist Forests of the Brazilian Amazon. Interciencia, 17, 8-18.

Casiano-Domínguez, M., Paz-Pellat, F., Rojo-Martínez, M., Covaleda-Ocanon, S., \& Raj, A. D. (2018). El carbono de la biomasa aérea medido en cronosecuencias: Primera estimación en México. Madera y Bosques, 24, e2401894.

Cerda Bustillos, R., Espin-Chion, T., \& Cifuentes, M. (2013). Carbono en sistemas agroforestales de cacao de la Reserva Indígena Bribri de Talamanca, Costa Rica. Agroforestería en las Américas, 49, 33-41.

Chen, X., \& Li, B. L. (2003). Change in Soil Carbon and Nutrient Storage after Human Disturbance of a Primary Korean Pine Forest in Northeast China. Forest Ecology and Management, 186, 197-206.

Comisión Nacional Forestal (CONAFOR) (2011). Situación actual y perspectivas de las plantaciones forestales comerciales en México (472 p.). México, D. F.

Cotler, H., Merino, L., \& Martinez-Trinidad, S. (2020) Forest Soil Management: A Mexican Experience. Open Journal of Soil Science, 10, 374-390. https://doi.org/10.4236/ojss.2020.109020

Coulombe, C. E., Wilding, L. P., \& Dixon, J. B. (2000). Vertisols. In M. E. Sumner (Ed.), Handbook of Soil Science (pp. 269-286). CRC Press.

Framstad, E., Wit, H., Mäkipää, R., Larjavaara, M., Vesterdal, L., \& Karltun, E. (2013). Biodiversity, Carbon Storage and Dynamics of Old Northern Forests. Nordic Council of Ministers. https://doi.org/10.6027/TN2013-507

Galicia, L., Gamboa, C. A. M., Cram, S., Chávez, V. B., Peña, R. V., Saynes, V., \& Siebe, C. (2016). Almacén y dinámica del carbono orgánico del suelo en bosques templados de México. Terra Latinoamericana, 34, 1-29.

Han, S. H., Meng, L., Park, G. S., Kim, S. B., Cho, M. S., \& Park, B. B. (2017). Characteristics of Soil Carbon and Nutrient Stocks across Land Use Types in a Forest Region of Central Korea. Forest Science and Technology, 13, 93-99. https://doi.org/10.1080/21580103.2017.1341434

Houghton, R. A. (2007). Balancing the Global Carbon Budget. Annual Review of Earth and Planetary Sciences, 35, 313-347. https://doi.org/10.1146/annurev.earth.35.031306.140057

Jobbágy, E. G., \& Jackson, R. B. (2000). The Vertical Distribution of Soil Organic Carbon 
and Its Relation to Climate and Vegetation. Ecological Applications, 10, 423-436. https://doi.org/10.1890/1051-0761(2000)010[0423:TVDOSO]2.0.CO;2

Jordán, A., Zavala, L. M., \& Bellinfante, N. (2007). Reserva de carbono en suelos forestales mediterráneos. In N. Bellinfante, \& A. Jordán (Eds.), Tendencias Actuales de la Ciencia del Suelo (pp. 638-647). Universidad de Sevilla.

Kim, C., Yoo, B. O., Jung, S. Y., \& Lee, K. S. (2017). Allometric Equations to Assess Biomass, Carbon and Nitrogen Stock of Black Pine and Red Pine Trees in Southern Korea. Forest-Biogeosciences and Forestry, 10, 483-490. https://doi.org/10.3832/ifor2164-010

Kuznetsova, A. I., Geraskina, A. P., Lukina, N. V., Smirnov, V. E., Tikhonova, E. V., Shevchenko, N. E., Gornov, A. V., Ruchinskaya, E. V., \& Tebenkova, D. N. (2021). Linking Vegetation, Soil Carbon Stocks, and Earthworms in Upland Coniferous-Broadleaf Forests. Forests, 12, 1179. https://doi.org/10.3390/f12091179

Lasco, R. D., \& Pulhin, F. B. (2003). Philippine Forest Ecosystems and Climate Change: Carbon Stocks, Rate of Sequestration and the Kyoto Protocol. Annals of Tropical Research, 25, 37-51.

Lasco, R. D., \& Pulhin, F. B. (2006). Assessing the Role of Watershed Areas in Mitigating Climate Change in the Philippines: The Case of the La Mesa Watershed. Journal of Environmental Science and Management, 9, 19-29.

Lewis, S. L. et al. (2009). Increasing Carbon Storage in Intact African Tropical Forests. Nature, 457, 1003-1006. https://doi.org/10.1038/nature07771

Li, D., Niu, S., \& Luo, Y. (2012). Global Patterns of the Dynamics of Soil Carbon and Nitro-Gen Stocks Following Afforestation: A Meta-Analysis. New Phytologist, 195, 172-181. https://doi.org/10.1111/j.1469-8137.2012.04150.x

Lorenz, K., \& Lal, R. (2009). Carbon Sequestration in Forest Ecosystems. Springer Science \& Business Media. https://doi.org/10.1007/978-90-481-3266-9

Lukina, N., Kuznetsova, A., Tikhonova, E., Smirnov, V., Danilova, M., Gornov, A., Bakhmet, O., Kryshen, A., Tebenkova, D., Shashkov, M., \& Knyazeva, S. (2020). Linking Forest Vegetation and Soil Carbon Stock in Northwestern Russia. Forests, 11, 979. https://doi.org/10.3390/f11090979

Malhi, Y. (2010). The Carbon Balance of Tropical Forest Regions, 1990-2005. Current Opinion in Environmental Sustainability, 2, 237-244. https://doi.org/10.1016/j.cosust.2010.08.002

Medina, G. G., Ruíz, C. J. A., \& Martínez, P. R. A. (1998). Los Climas de México: Una Estratificación Ambiental Basada en el Componente Climático (p. 99). Instituto Nacional de Investigaciones Forestales, Agrícolas y Pecuarias: Guadalajara, México.

Navarro-Martínez, J., Godínez-Jaimes, F., López-López, M. A., Rosas-Acevedo, J. L., Juárez-López, A. L., \& Reyes-Umaña, M. (2020). Fitting Allometric Equations to Estimate Aboveground Biomass for Pinusoocarpa and Quercusresinosa at Guerrero, Mexico. Madera y Bosques, 26, e2611964. https://doi.org/10.21829/myb.2020.2611964

Pulhin, F. B. (2007). Quantifying Nitrous Oxide Emissions from the Secondary Forests and Tree Plantations of Mt. Makiling Forest Reserve (60 p.). Project Final Report, University of the Philippines Los Baños, College.

Racelis, E. L., Racelis, D. A., \& Luna, A. C. (2019). Carbon Sequestration by Large Leaf Mahogany (Swietenia macrophylla King.) Plantation in Mount Makiling Forest Reserve, Philippines: A Decade after. Journal of Environmental Science and Management, 22, 67-76.

Rojas-García, F. H., Santoyo-Gómez, G., González-Montiel, E., Velázquez-Rodríguez, A., \& Pulido-Ponce, J. I. (2017). La ciencia del suelo en el ciclo del carbono de México. Elementos para Políticas Públicas, 1, 69-96. 
Saimun, S. R., Karim, R., Sultana, F., \& Arfin-Khan, M. A. S. (2021). Multiple Drivers of Tree and Soil Carbon Stock in the Tropical Forest Ecosystems of Bangladesh. Trees, Forests and People, 5, 100-108. https://doi.org/10.1016/j.tfp.2021.100108

SEMARNAT (2002). Norma Oficial Mexicana NOM-021-RECNAT-2000, que establece las especificaciones de fertilidad, salinidad y clasificación de suelos. Estudios, muestreo y análisis (73 p.). Secretaría de Medio Ambiente y Recursos Naturales. México.

Sierra, C. A., del Valle, J. I., \& Restrepo, H. I. (2012). Total Carbon Accumulation in a Tropical Forest Landscape. Carbon Balance and Management, 7, 12. https://doi.org/10.1186/1750-0680-7-12 